\title{
CORRESPONDENCE
}

\section{Comments on the paper 'Fission-track dating of British Ordovician and Silurian stratotypes' by R. J. Ross and others}

SIR - Fission track ages of British Ordovician and Silurian stratotypes were first published in abbreviated form by Ross et al. (1978); now that they have been fully published (Ross et al. 1982) it is possible to assess their significance more carefully.

The earlier brief account of their data was hailed by some (e.g. Compston, 1979; McKerrow, Lambert \& Chamberlain, 1980) as providing a considerable advance in the numerical calibration of the Phanerozoic time scale. This is an opinion not shared by fission track experts (e.g. Hurford \& Green, 1982; Storzer \& Wagner, 1982). Though the stratigraphy of the horizons which Ross $e t$ al. (1982) attempted to date by the fission track method is unexceptionable it is necessary to take account of Hurford \& Green's (1982) warning that adequate safeguards must be taken against the addition of misleading data resulting from the related problems of uncertainties in both $\lambda_{f}$ (the $238 \mathrm{U}$ fission track decay constant) and neutron dosimetry. Storzer \& Wagner (1982), though suggesting that future improvements in neutron dosimetry and age standards may eventually reduce errors in the accuracy of fission track ages below the present realistic figure of $\pm 10 \%$, commented that Ross $e t$ al. were apparently unaware of the efficiency problems in the external detector technique for zircons, that they did not consider adequately the possibility of fossil-track fading in zircon, and expressed surprise that they quoted fission track ages with errors as small as $\pm 2 \%$.

Ross et al. (1982) consistently and seriously underestimated the errors to be attached to their fission track ages. Apart from apparently unassessed errors due to flux perturbation (see Storzer \& Wagner, 1982, pp. 213-14), both Storzer \& Wagner (1982) and Hurford \& Green (1982) stressed the difficulty in the fission track method of accurate measurement of the neutron fluence, even when this is attempted by use of the National Bureau of Standards standard glasses SRM 961-4. The only effective way to avoid this inaccuracy, together with the important remaining uncertainties in the fission decay constant and the fission cross section, is to use an age-standard which is irradiated simultaneously with each batch of samples of unknown age.

Apart from the fact that there is as yet no fission track age standard which meets all the necessary criteria of reliability for comparison with other radiometric dating schemes (see Storzer \& Wagner, 1982, p. 214), Ross et al. did not follow this procedure. Instead they attempted to relate their fission track ages to the $\mathrm{K}-\mathrm{Ar}$ age of a standard via neutron fluence measurement made by including in each run their laboratory standard glass, itself calibrated against SRM 962 and SRM 963 using the Cu calibration. Their procedure for relating fission track ages to the $\mathrm{K}-\mathrm{Ar}$ age of a standard is given by Naeser, Hurford \& Gleadow (1977). As was demonstrated by Hurford \& Green (1982), this procedure introduces an extra component of at least $\pm 3 \%$ into the absolute error to be attached to each fission track age quoted by Ross et al. (1982). As an example, the error for their Ludlovian Sample $76 \mathrm{Sh} 25$ cannot be as low as the quoted $\pm 9 \mathrm{Ma}$; on an absolute basis the compounded error must be at least as large as $\pm 15 \mathrm{Ma}(1 \sigma)$ for the quoted age of $407 \mathrm{Ma}$. The lack of a suitable K-Ar standard caused Ross et al. (1982) to write: 'It is possible, therefore, that fission track ages in the early Palaeozoic may differ by a per cent or two from $\mathrm{K}-\mathrm{Ar}$ '.

More serious is the fact that in their statistical computation of errors Ross et al. (1982) used a statistical formula, given by Naeser, Johnson \& McGee (1978), which few believe to be applicable to fission track data. Green (1981) criticized the restatement of this approach by Johnson, McGee \& Naeser (1979), who in our view failed in their reply (Johnson, McGee \& Naeser, 1982) to establish the correctness of their procedure. Briefly, the crux of the matter is that Johnson, McGee \& Naeser (1979) proposed a formula which reduced the estimate of the standard deviation of the ratio $\rho_{s} / \rho_{t}$, used to compute a fission track age $\left(\rho_{g}\right.$ is the spontaneous track density in the mineral to be dated, $\rho_{i}$ is the thermal neutron induced track density), by introducing an extra negative term depending on an assumed statistical correlation between $\rho_{g}$ and $\rho_{i}$. In their defence of this procedure Johnson, McGee \& Naeser (1982) stated correctly that both $\rho_{8}$ and $\rho_{i}$ are functions of the uranium concentration in the mineral to be dated and deduce that $\rho_{\mathrm{s}}$ and $\rho_{i}$ are correlated, and are physically dependent

Geol. Mag. 120 (3), 1983, pp. 295-302. Printed in Great Britain. 
on each other. This is unexceptionable, though it might be clearer to state that $\rho_{g}$ and $\rho_{i}$ are functionally related (for the equations relating them, see Faure, 1977). However it is implicit in the development of their formula for $\sigma\left(\rho_{s} / \rho_{i}\right)$ - the standard deviation of $\rho_{s} / \rho_{t}$ - that Johnson, McGee $\&$ Naeser (1979) assumed that the measurements of $\rho_{s}$ and $\rho_{i}$ are statistically dependent; this is explicitly stated in Johnson, McGee \& Naeser (1982). They are not. The fact that there is a functional relationship between two quantities $\rho_{s}$ and $\rho_{i}$ does not necessarily imply that the measurements of $\rho_{s}$ and $\rho_{i}$ are statistically dependent, as is lucidly explained by Mandel (1964). Functional dependence relates to the expected values of statistical populations, whereas statistical dependence relates to the fluctuating parts of the measurements, that is, to the deviation of observations from their expected values. Since the measurements of $\rho_{s}$ and $\rho_{i}$ (as track densities) are made quite independently of each other in two separate observations, $\sigma\left(\rho_{s}\right)$ and $\sigma\left(\rho_{i}\right)$ are necessarily statistically independent with zero correlation coefficient, although the expected values of $\rho_{s}$ and $\rho_{i}$ are highly correlated through the uranium concentration. What Johnson, McGee \& Naeser (1982) stigmatized as the 'early practice' is, in fact, the correct practice. The errors quoted in Ross et al. (1982) are consequently too low, and should be recalculated according to the conventional statistics outlined by Green (1981).

That this is not an unimportant quibble may be illustrated by one example. The age quoted by Ross et al. (1982) of $434 \pm 12(1 \sigma)$ Ma for sample 76 DL 39 for the Ashgillian Upper Hartfell Shale becomes $434 \pm 20(1 \sigma) \mathrm{Ma}$ for the precision alone if conventional statistics (Green, 1981) are used; on an absolute basis, compounding the error due to the method of neutron fluence measurement, this becomes $434 \pm 24(1 \sigma) \mathrm{Ma}$. Note in passing that this fission track age agrees within error with the Ashgillian Stockdale Rhyolite age of $421 \pm 5(2 \sigma) \mathrm{Ma}$.

Even were one to neglect all of the foregoing factors, it cannot be too strongly stressed that Ross et al. (1982) quoted their errors at the $1 \sigma$ level. Even the intercomparison between themselves of the fission track ages requires at least $2 \sigma$ errors to be employed, and this is yet more necessary if comparisons are to be made between fission track ages and ages based on other radiometric dating methods. As a result, even the most precise fission track age quoted by Ross et al. (1982, their Table 1) has an associated analytical error of at least $\pm 18 \mathrm{Ma}$, ranging up to $\pm 42 \mathrm{Ma}$ in the worst case. Even these errors should in fact be considerably increased to include the additional uncertainties mentioned above.

One is left with the clear impression that the true $95 \%$ absolute error to be associated with these fission track dates is about $\pm 10 \%$ or more than the duration of the Silurian Period, which makes them of little value for the numerical calibration of the Phanerozoic time scale. This conclusion is confirmed by Hurford (private comm., 1982) on the basis of attempts to reproduce the ages of putative standards. Storzer \& Wagner (1982) took an even more pessimistic view, setting the $68 \%$ accuracy even of fission track ages obtained by using age-standards at $\pm 10 \%$ and pointing to the large variations in the estimates by fission track dating of the age of the KBS Tuff in northern Kenya. The fission track ages of Ross et al. (1982) cannot bear comparison with other geochronological methods, which have yielded ages with $95 \%$ accuracies of $\pm 2 \%$ in the Phanerozoic, but at the same time their work has demonstrated the potential contribution which fission track dating could make to stratigraphical studies in the future.

Ross et al. (1982) went to considerable length to demonstrate the incorrectness of the revised fission track ages given by Gale, Beckinsale \& Wadge (1979 $a$ ). That revision was certainly incorrect because we based it directly on the account of the principles of fission track dating given by Naeser (1979) and because Ross et al. (1978) did not state that their fission track ages were calibrated against $\mathrm{K}-\mathrm{Ar}$ ages. However, we corrected our mistake in our later paper (Gale, Beckinsale \& Wadge, 1980 a paper quoted by Ross et al. in their list of references). Nevertheless Ross et al. (1982), two years later, criticized our initial error even to the extent of reproducing as their Table 4 a table which originally appeared in almost identical form on page 13 of Gale, Beckinsale \& Wadge (1980).

In their discussion of other results pertinent to the Palaeozoic time scale Ross et al. (1982) concentrated considerable attention on the discussion in Gale, Beckinsale \& Wadge (1979a) and failed to note the revised discussion in Gale, Beckinsale \& Wadge (1980), which not only took account of 34 radiometric dates relevant to the numerical calibration of the Ordovician, Silurian and Devonian time scales but also demonstrated how poor a constraint the present fission track ages provide for that calibration. Now that it is known that the published errors for the fission track ages are underestimated, the constraint becomes even poorer.

There is an unfortunate emphasis in Ross et al. (1982) on the $\mathrm{Rb}-\mathrm{Sr}$ whole rock isochron date for 
the Stockdale Rhyolite (Gale, Beckinsale \& Wadge, 1979a). There is no radiometric date yet reported which has been proved to be so completely reliable that it can be used as an anchor point in calibrating the Palaeozoic time scale. Such a calibration must instead be based on all available reliable data, an approach taken by Gale, Beckinsale \& Wadge (1980), by McKerrow, Lambert \& Chamberlain (1980) and by Gale (1982).

Though undue weight should not be given to the Stockdale Rhyolite age of $421 \pm 5 \mathrm{Ma}$ ( $2 \sigma$ error) for the Ashgill, nevertheless Ross et al. have presented no data which refutes it. Their own fission track age for the Rawtheyan Upper Hartfell Shale is $434 \pm 24 \mathrm{Ma}(2 \sigma)$ even if the authors' own low error estimate is used; it has been shown earlier in this paper that this age should really be quoted as $434 \pm 40 \mathrm{Ma} \mathrm{(2 \sigma )}$. This overlaps with the age for the Stockdale Rhyolite whichever error estimate is used, so there is no conflict here. Neither are the two Lower Silurian fission track dates of $437 \pm 20 \mathrm{Ma}$ and $422 \pm 20 \mathrm{Ma}$ for the Birkhill Shale and the Buildwas Formation in conflict with the Stockdale Rhyolite age. Moreover the Lower Llandoverian age of $431 \pm 7(2 \sigma)$ Ma obtained by Lanphere $e t$ al. (see Item NDS 128 in Odin, 1982) for Esquibel Island, though questioned by Rundle on both geochronological and stratigraphical grounds (see Odin, 1982, p. 478), is now recognized not to be in conflict with the Stockdale Rhyolite data (Gale, 1983). Finally, the data quoted by Ross et al. (1982) for the Lower Ludlovian Middle Elton Formation are a fission track age of $407 \pm 18$ (2o) Ma and a K-Ar age of $419 \pm 10(2 \sigma) \mathrm{Ma}$; when we note that the more precise K-Ar age spans a range of 409 to $429 \mathrm{Ma}$ and note that the duration of the Silurian Period is no longer than $25 \mathrm{Ma}$ we again see that this presents no conflict with the Stockdale Rhyolite age. There is thus no direct evidence for the statement by Ross et al. (1982) that Gale Beckinsale \& Wadge (1979a) 'determined precisely the wrong number as a measure of the age of emplacement for the Stockdale Rhyolite', whilst there is evidence that Ross et al. (1982) determined very imprecisely the ages of a number of formations whose stratigraphy is precisely established.

Ross et al. (1982) are, therefore, left merely with their prejudice against $\mathrm{Rb}-\mathrm{Sr}$ whole rock isochron ages on acid rocks. Gale, Beckinsale \& Wadge (1979b), complemented by Gale, Beckinsale \& Wadge (1980), presented a body of evidence showing that, although the Rb-Sr system is easily disturbed in acid pyroclastics, $\mathrm{Rb}-\mathrm{Sr}$ whole rock isochron ages for rhyolite lavas can often reliably date their time of extrusion. An excellent recent example is the work by Williams et al. (1982) on the Cerberean Volcanics in Australia; they obtained a mean Rb-Sr biotite-whole rock age of $367 \pm 3 \mathrm{Ma}$ and a mean $\mathrm{K}-\mathrm{Ar}$ biotite age of $366 \pm 5 \mathrm{Ma}$ for the biotite rhyodacite, whilst the contemporaneous basal rhyolite yielded a $\mathrm{Rb}-\mathrm{Sr}$ isochron age for whole rocks and feldspars of $369 \pm 3 \mathrm{Ma}$.

Against this evidence Ross et al. advanced merely a statement, given apparently the status of dogma, by Van Schmus, Thurman \& Peterman (1975) which had already been examined by Gale, Beckinsale \& Wadge $(1979 b, 1980)$. First, we may note that this statement questioned the acceptance not only of $\mathrm{Rb}-\mathrm{Sr}$ whole rock isochrons for acid volcanics but also for granites; if this were to be accepted as a general rule it would eliminate many of the data usually accepted as reliable for time-scale calibration and would ignore excess argon or resetting problems with $\mathrm{K}-\mathrm{Ar}$ dates, problems with $\mathrm{U}-\mathrm{Pb}$ dates due to inherited zircons, etc. Second, Van Schmus, Thurman \& Peterman (1975) based their statement merely on a comparison between $\mathrm{U}-\mathrm{Pb}$ zircon dates and $\mathrm{Rb}-\mathrm{Sr}$ whole rock isochron dates for Middle Precambrian rocks in Wisconsin; they provided no evidence that their problem could not instead have been explained in terms of the zircon age being inherited from the source region of the rocks, as for instance in the case documented by Pankhurst \& Pidgeon (1976). Third, in a later refinement of their position Van Schmus \& Bickford (1976) stressed the view that Rb-Sr whole rock isochron ages can sometimes be $10-20 \%$ too young for epizonal or fine-grained supracrustal Precambrian rocks which have low total $\mathrm{Sr}$ concentrations and high $\mathrm{Rb} / \mathrm{Sr}$ ratios. None of these characteristics appertain to the Stockdale Rhyolite, which was moreover proved by Gale, Beckinsale \& Wadge (1979a) to be extrusive and not of ignimbritic or ash flow tuff origin.

Perhaps the most convincing demonstration that $\mathrm{Rb}-\mathrm{Sr}$ whole rock isochron ages for rhyolites are not incompatible with other types of radiometric dates used for calibrating the time scale is to list those ages within the Ordovician, Silurian and Devonian periods which appear to be based on sound stratigraphy and reliable geochronology; this is done in Table 1. In Figure 1 these ages are plotted for illustrative and comparative purposes against a stratigraphic axis in a way similar to that adopted by Boucot (1975), McKerrow, Lambert \& Chamberlain (1980) and others. It is clear that a line drawn so as to pass through all items passes also through the $\mathrm{Rb}-\mathrm{Sr}$ isochron ages for acid rocks, items $7,9,13,15$ and 32. Figure 1 also demonstrates that the Stockdale Rhyolite age is compatible with 


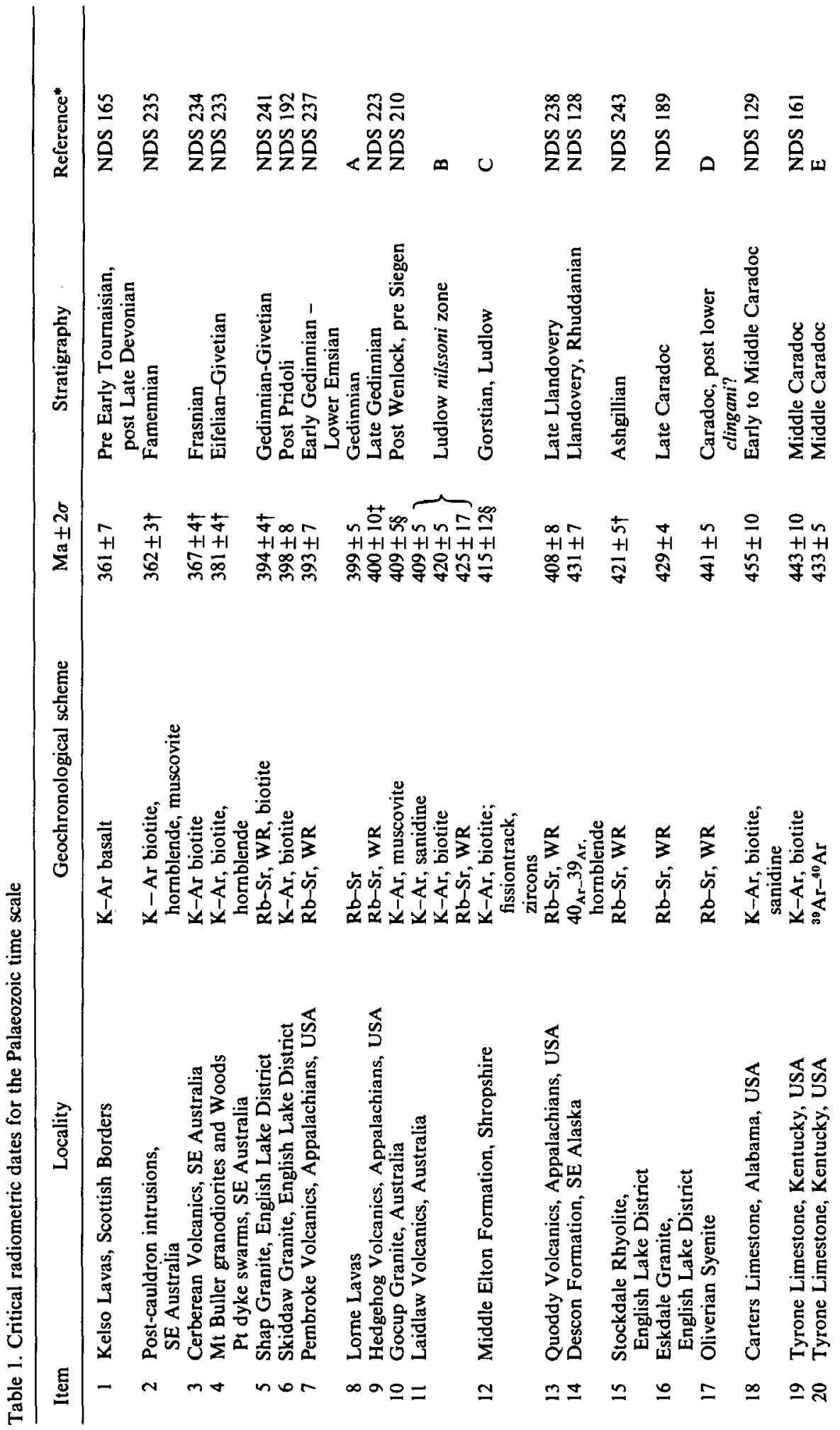




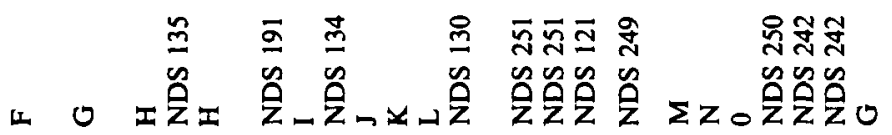

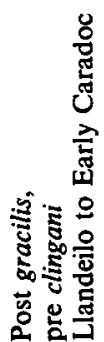

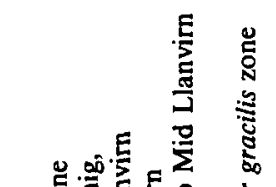

䒘范茞点

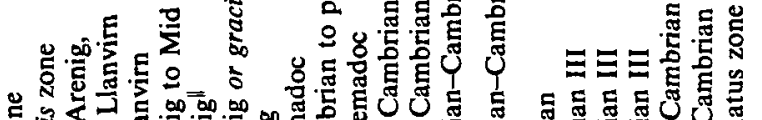

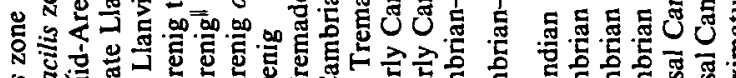

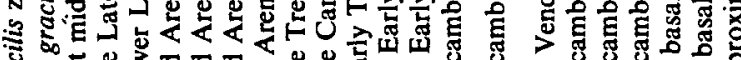

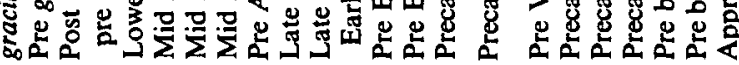

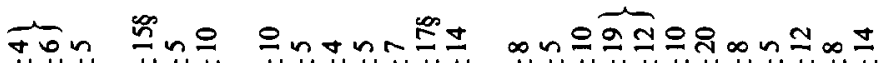
$+1+1+1 \quad+1+1 \quad+1+1+1+1+1+1 \quad+H+1+1+1+1+1+++1+1+1$

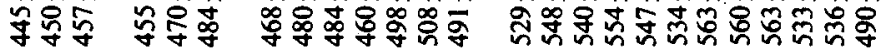

芬

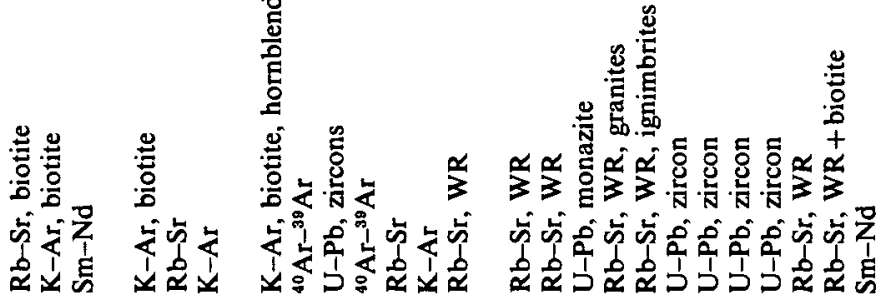

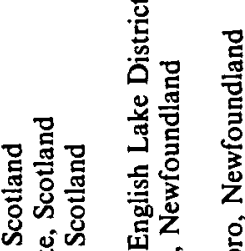

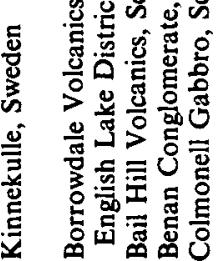
i

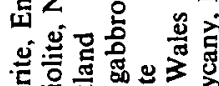

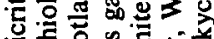

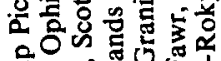

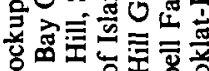

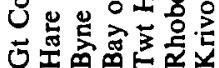
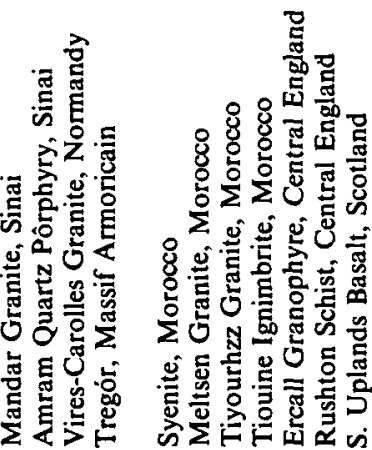

สิ สิกับ

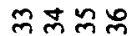

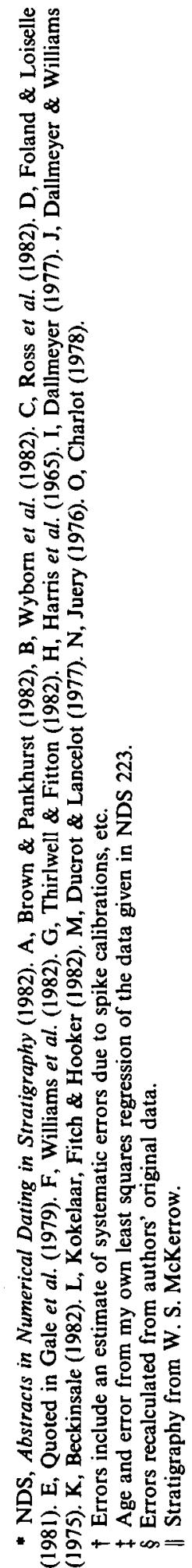




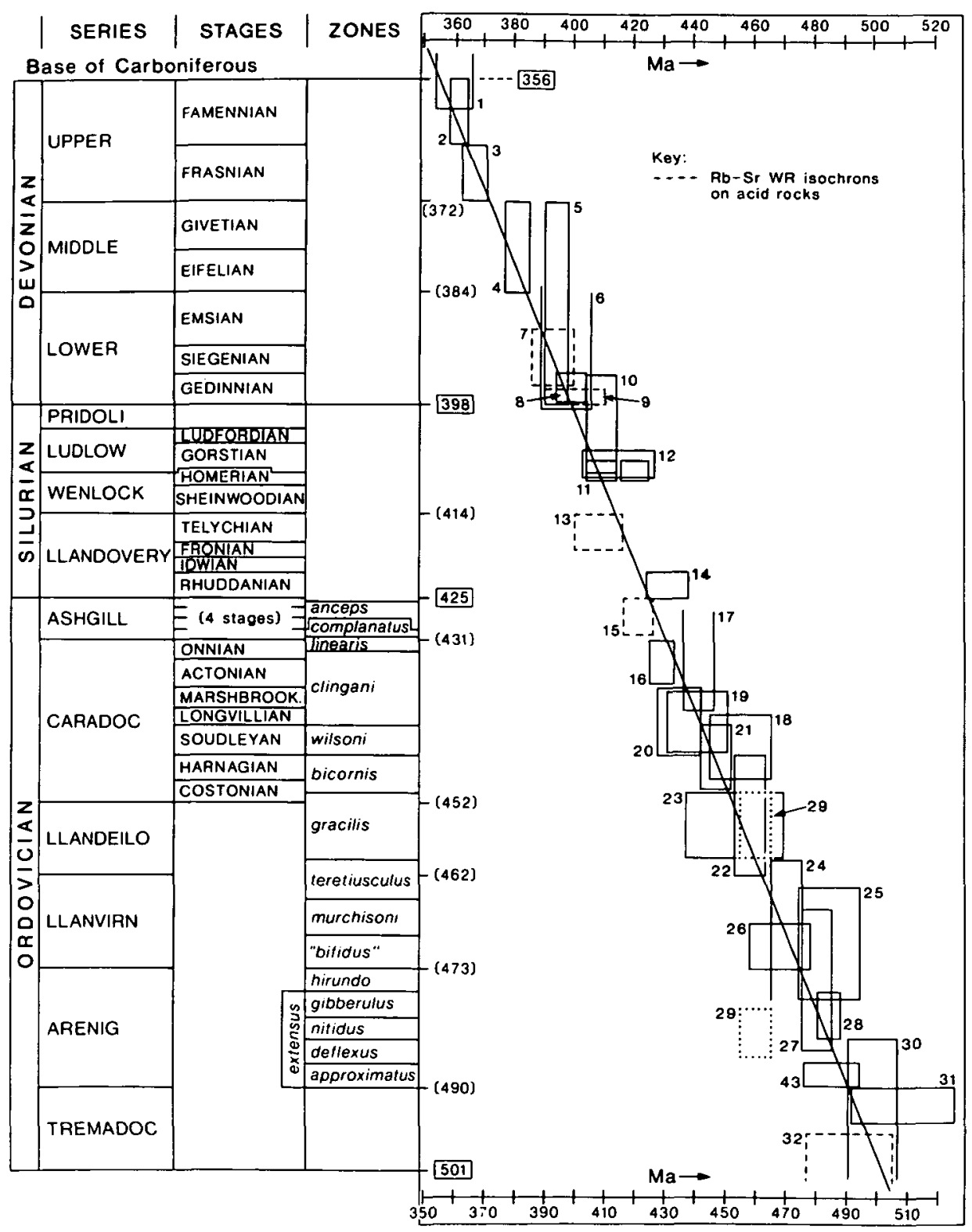

Figure 1. Plot of critical radiometric ages against a stratigraphic axis where the relative lengths of the stages and zones have been chosen to be consistent with the rather subjective estimates made by palaeontologists and stratigraphers. The numbers of the items correspond with the list given in Table 1. Two sigma errors for the ages are used throughout. $\mathrm{Rb}-\mathrm{Sr}$ isochron ages on acia volcanics are distinguished by a broken line. The stratigraphic evidence for the Bay of Islands gabbro, item 29, places it either in the mid Arenig or in the gracilis zone; the correlation with other data shows that it must be placed unequivocally in the gracilis zone. 
those few other ages near the Silurian/Ordovician boundary. The estimates for the bases of the Carboniferous, Devonian and Silurian periods given in Figure 1 are uncertain within an error of about $\pm 5 \mathrm{Ma}$. The Ordovician base, given in Figure 1 as $501 \mathrm{Ma}$, is less well established; the base of the Tremadoc in Figure 1 could be moved down (without destroying the fit to the line of Items 31 and 32) as far as about $509 \mathrm{Ma}$. No great significance should be attached to the estimates placed in brackets in Figure 1 for the bases of the series, but the estimates for the beginnings of the periods are rather more soundly based than those advanced by Ross et al. (1982).

\section{REFERENCES}

Beckinsale, R. D. 1982. (pers. comm.).

Boucot, A. J. 1975. Evolution and Extinction Rate Controls. Amsterdam: Elsevier.

Brown, J. F. \& Pankhurst, R. J. 1982. In Igneous Rocks of the British Isles (ed. D. S. Sutherland), p. 580. Chichester: Wiley.

Charlot, R. 1978. Thèse. Doct. Etat. Université de Rennes, France.

Compston, W. 1979. The place of isotopic age determinations in stratigraphy. Episodes (IUGS), vol. $1,10-13$.

Dallmeyer, R. D. 1977. Am. J. Sci. 277, 61-72.

Dallmeyer, R. D. \& Williams, H. 1975. Can. J. Earth Sci. 12, 1685-90.

Ducrot, J. \& Lancelot, J. R. 1977. Can. J. Earth Sci. 14, 2771-7.

Faure, G. 1977. Principles of Isotope Geology. New York: Wiley.

Foland, K. A. \& Loiselle, M. C. 1981. Bull. geol. Soc. Am. 92, 179-88.

Gale, N. H. 1982. Numerical Dating of Caledonian times (Cambrian to Silurian). In Numerical Dating in Stratigraphy, vol. 1 (ed. G. S. Odin), pp. 467-86. Chichester: Wiley.

Gale, N. H. 1983. Numerical calibration of the Palaeozoic time scale. In Geochronology and the Geological Record, Geol. soc. Lond. (In the Press).

Gale, N. H., Beckinsale, R. D. \& Wadge, A. J. 1979(a). A Rb-Sr whole rock isochron for the Stockdale Rhyolite of the English Lake District and a revised mid-Palaeozoic time-scale. J. geol. Soc. Lond. 136, 235-42.

Gale, N. H., Beckinsale, R. D. \& Wadge, A. J. 1979(b). Rb-Sr whole rock dating of acid rocks. Geochem. J. 13, 27-9.

Gale, N. H., Beckinsale, R. D. \& Wadge, A. J. 1980. Discussion of a paper by McKerrow, Lambert and Chamberlain on the Ordovician, Silurian and Devonian time scales. Earth Planet. Sci. Lett. 51, 9-17.

Green, P. F. 1981. A new look at statistics in fission track dating. Nucl. Tracks 5, 77-86.

Harris, P. M. et al. 1965. Nature, Lond. 205, 352-3.

Hurford, A. J. \& Green, P. F. 1982. A users' guide to fission track dating calibration. Earth Planet. Sci. Lett. 59, 343-54.

Johnson, N. M., McGee, V. E. \& Naeser, C. W. 1979. A practical method of estimating standard error of age in the fission track dating method. Nucl. Tracks 3, 93-9.

Johnson, N. M., McGee, V. E. \& Naeser, C. W. 1982. Reply to P. F. Green's criticism of 'A practical method of estimating standard error of age in the Fission Track Dating Method'. Nucl. Tracks 6, 53-7.

Juery, A. 1976. These. Doct. Etat, Université de Rennes, France.

Kokelaar, B. P., Fitch, F. J. \& Hooker, P. J. 1982. Geol. Mag. 119, 207-11.

Mandel, J. 1964. The Statistical Analysis of Experimental Data. New York: Interscience, Wiley.

McKerrow, W. S., Lambert, R. St. J. \& Chamberlain, V. E. 1980. The Ordovician Silurian and Devonian time scale. Earth Planet. Sci. Lett. 51, 1-8.

Naeser, C. W. 1979. Fission track dating and geologic annealing of fission tracks. In Lectures in Isotope Geology (ed. E. Jäger and J. C. Hunzicker), pp. 154-69. Berlin: Springer.

Naeser, C. W., Hurford, A. J. \& Gleadow, A. J. W. 1977. Fission track dating of pumice from the KBS tuff, East Rudolf, Kenya. Nature, Lond. 284, 225-30.

Naeser, C. W., Johnson, N. M. \& McGee, V. E. 1978. A practical method of estimating standard error of age in the fission track dating method. In Short Papers of the Fourth International Conference on Geochronology, Cosmochronology and Isotope Geology, Aspen, Colorado. U.S. geol. Surv. Open-File Rep. 78-701, 303-4. 
Odin, G. S. 1982. (ed.) Numerical Dating in Stratigraphy, in two parts. Chichester: Wiley.

Pankhurst, R. J. \& Pidgeon, R. T. 1976. Inherited isotope systems and the source region pre-history of Early Caledonian granites in the Dalradian series of Scotland. Earth Planet. Sci. Lett. 31, 55-68.

Ross, R. J. et al. 1978. Fission track dating of Lower Palaeozoic bentonites in British stratotypes. In Short Papers of the Fourth International Conference on Geochronology (ed). R. E. Zartman. U.S. geol. Surv. Open File Rep. 78-701, 363-7.

Ross, R. J., Naeser, C. W., Izett, G. A., Obradovich, J. D. Basset, M. G., Hughes, C. P., Cocks, L. R. M., Dean, W. T., Ingham, J. K., Jenkins, C. J., Rickards, R. B., Sheldon, P. R., Toghill, P., Whittington, H. B. \& Zalasiewicz, J. 1982. Fission track dating of British Ordovician and Silurian stratotypes. Geol. Mag. 119, 135-53.

Storzer, D. \& Wagner, G. A. 1982. The application of fission track dating in stratigraphy: a critical review. In Numerical Dating in Stratigraphy (ed. G. S. Odin), pp. 199-224. Chichester: Wiley.

Thirlwell, M. F. \& Fitton, J. G. 1983. J. geol. Soc. Lond. (In the Press).

Van Schmus, W. E. \& Bickford, M. E. 1976. Rotation of Rb-Sr isochrons during low-grade events. Abstracts for European Colloquium on Geochronology. Amsterdam.

Van Schmus, W. R., Thurman, E. M. \& Peterman, Z. E. 1975. Geology and Rb-Sr chronology of Middle Precambrian rocks in Eastern and Central Wisconsin. Bull. geol. Soc. Am. 86, 1255-65.

Williams, I. S., Tetley, W., Compston, W. \& McDougall, I. 1982. A comparison of K-Ar and Rb-Sr ages of rapidly cooled igneous rocks: two points in the Palaeozoic time scale re-evaluated. $J$. Geol. Soc. Lond. 139, 557-68.

Wyborn, D. et al. 1982. Earth Plan. Sci. Lett. 59, 90-100.

Department of Geology and Mineralogy

N. H. GALE

Parks Road.

Oxford, OXI 3PR

Institute of Geological Sciences, (NERC)

Exhibition Road

London, SW7.

(who publishes with the approval of the Director, Institute of Geological Sciences (NERC).)

28th October 1982 